\title{
MGBG-cisplatin combination chemotherapy against breast cancer
}

\author{
Raquel F Gonsalves ${ }^{1 *}$, Maria PM Marques ${ }^{1,2}$ \\ From 16th International Charles Heidelberger Symposium on Cancer Research \\ Coimbra, Portugal. 26-28 September 2010
}

Worldwide, it is estimated that more than one million women are diagnosed with breast cancer every year, representing $14 \%$ of female cancer deaths [1], about 4,500 new cases being detected each year in Portugal. In the present study, the compound metylglyoxal bis(guanylhydrazone) (MGBG) [2], an inhibitor of S-adenosylL-methionine descarboxylase (SAMdc), was investigated as a potencial anti-cancer agent towards the breast cancer cell line MCF-7 and the non-carcinogenic, nonimmortalized, human foreskin fibroblast cells BJ. The results (MTT assay) evidenced that the effect of MGBG against the MCF-7 cells is dose and time dependent, revealing a significant cell viability loss $(c a .90 \%$ at $72 \mathrm{~h}$, for a $50 \mu \mathrm{M}$ dosage). Since its effect was not shown to be reversible, this compound appears to be quite effective in this line. In fact, compared to cisplatin (cDDP), a commonly used drug in clinical practice, MGBG provided a larger cytotoxicity in the same concentration range. Similarly, a slight synergistic effect was verified for these two compounds - ca. $93 \%$ at $72 \mathrm{~h}$, for an MGBG(50 $\mu \mathrm{M}): \operatorname{CDDP}(10 \mu \mathrm{M})$ combination, while no effect was assessed on the reversibility of the cytotoxic action. Regarding the non-neoplastic BJ line, MBGB exhibited a clear reversibility of et growth-inhibiting effect, as opposed to cDDP and the MGBG:cDDP cocktails.

\section{Author details \\ "Molecular Physical-Chemistry" R\&D Unit, University of Coimbra, Coimbra, Portugal. ${ }^{2}$ Department of Life Sciences, Faculty of Sciences and Technology, University of Coimbra, Coimbra, Portugal.}

Published: 24 September 2010

\footnotetext{
* Correspondence: raquel.fg7@gmail.com

"'Molecular Physical-Chemistry" R\&D Unit, University of Coimbra, Coimbra, Portugal

Full list of author information is available at the end of the article
}

\section{References}

1. Coughlin SS, Ekwueme DU: Breast cancer as a global health concern. Cancer Epidemiol 2009, 33:315-318.

2. Marques MPM, Gil FPSC, Calheiros R, Battaglia V, Brunati AM, Agostinelli E, Toninello A: Biological activity of antitumoural MGBG: the structural variable. Amino Acids 2008, 34:555-564.

doi:10.1016/j.canep.2009.10.003

Cite this article as: Gonsalves and Marques: MGBG-cisplatin combination chemotherapy against breast cancer. BMC Proceedings 2010 4(Suppl 2):P27.
Submit your next manuscript to BioMed Central and take full advantage of:

- Convenient online submission

- Thorough peer review

- No space constraints or color figure charges

- Immediate publication on acceptance

- Inclusion in PubMed, CAS, Scopus and Google Scholar

- Research which is freely available for redistribution
C Biomed Central 